\title{
TESTOSTERONE LEVELS IN THE SERUM AND TESTES OF GROWING RATS FOLLOWING PRENATAL EXPOSURE TO BUSULPHAN
}

\author{
R. W. HALL AND W. R. GOMES \\ Animal Reproduction Teaching and Research Center, \\ The Ohio State University, Columbus, Ohio 43210, U.S.A.
}

(Received 19th March 1973)

In 1963, Hemsworth \& Jackson reported that rats given an injection of busulphan (Myleran; 1,4-dimethane-sulphonoxybutane) during Days 11 to 14 of gestation produced sterile male offspring. Exposure to busulphan during Days 13 to 15 of development selectively destroyed developing germ cells in the embryonic testis (Hemsworth \& Jackson, 1963; Gaulier \& Roux, 1970). Earlier exposure also resulted in teratogenic changes in the fetus (Gaulier \& Roux, 1970). Since busulphan treatment during the period described above results in testes without spermatogonia, but with apparently normal Sertoli and Leydig cells, animals with this 'Sertoli cell only' condition may be of use in studying the rôle of spermatogenic elements in producing or metabolizing androgens or 'inhibin' (Debeljuk, Arimura \& Schally, 1973; Gomes, Hall, Jain \& Boots, 1973). This study was undertaken to determine the testosterone levels in the testes and serum of rats exposed prenatally to busulphan.

Adult female Wistar rats were paired with fertile males until spermatozoa were detected in a vaginal smear. On the day of mating (Day 0 ), the male was removed and the female was randomly assigned to one of two experimental groups.

On Day 13, each female was injected intraperitoneally with busulphan (10 mg/kg body wt) or with the vehicle (arachis oil) alone and allowed to litter normally. At 21, 40 and 60 days after birth, male offspring were weighed and exsanguinated by cardiac puncture under sodium pentobarbital anaesthesia. The seminal vesicles, except in the 21 day-old group, and the testes were removed and weighed. Testis samples taken for histological examination were fixed in Bouin's solution, embedded in paraffin wax, and sectioned at $5 \mu \mathrm{m}$. The sections were stained in haematoxylin and eosin and examined under the light microscope. The remaining testis tissue was weighed, homogenized in distilled water and stored at $-20^{\circ} \mathrm{C}$ until required for assay. Serum was separated from clotted blood samples and also stored at $-20^{\circ} \mathrm{C}$. Testosterone levels were assayed in ether extracts of serum and tissue homogenates using the radioimmunoassay procedure described by Gomes et al. (1973). The average recovery of testosterone was 78 to $85 \%$; testosterone levels were corrected for procedural losses. The minimum sensitivity of the method was $50 \mathrm{pg}$ testosterone and the coefficient of variation for duplicate samples was $8 \%$. 
As shown in Table 1, male rats exposed to busulphan in utero had lower body weights than controls at 21 (not significant), $40(P<0.01)$ and $60 \quad(P<0.01)$ days of age. Testis weights were lower $(P<0.01)$ in treated rats in all three age groups and the seminal vesicles of rats treated with busulphan were smaller $(P<0.01)$ in both age groups where these glands were weighed. Adjustment of testis and seminal vesicle weights for differences in body weight, by analysis of covariance (Harvey, 1960), reduced the difference in seminal vesicle weights to non-significant levels; the testes of treated rats were smaller $(P<0 \cdot 01)$ even after adjustment.

No teratogenic changes were found in treated rats and their health, vigour and activity appeared normal.

Table 1. Body, testis, and seminal vesicle weights of rats exposed prenatally to busulphan

\begin{tabular}{c|l|r|c|c|c}
\hline $\begin{array}{c}\text { Age } \\
(\text { days })\end{array}$ & $\begin{array}{c}\text { Treatment } \\
\text { group }\end{array}$ & $\mathrm{n}$ & $\begin{array}{c}\text { Body wt } \\
(\mathrm{g})\end{array}$ & $\begin{array}{c}\text { Testis wt } \\
(\mathrm{g})\end{array}$ & $\begin{array}{c}\text { Seminal vesicle wt } \\
(\mathrm{mg})\end{array}$ \\
\hline 21 & Control & 14 & $37 \cdot 4 \pm 1.8$ & $0 \cdot 23 \pm 0 \cdot 01$ & - \\
& Busulphan & 8 & $32 \cdot 4 \pm 2 \cdot 0$ & $0 \cdot 06 \pm 0 \cdot 06$ & - \\
40 & Control & 10 & $122 \cdot 0 \pm 5 \cdot 0$ & $1 \cdot 36 \pm 0 \cdot 06$ & $43 \cdot 0 \pm 4 \cdot 2$ \\
& Busulphan & 7 & $80 \cdot 1 \pm 5 \cdot 8^{* *}$ & $0 \cdot 21 \pm 0 \cdot 01$ & $19 \cdot 0 \pm 1 \cdot 9 * *$ \\
60 & Control & 10 & $229 \cdot 1 \pm 6 \cdot 2$ & $2 \cdot 74 \pm 0 \cdot 04$ & $262 \cdot 9 \pm 13 \cdot 1$ \\
& Busulphan & 6 & $162 \cdot 8 \pm 6 \cdot 8^{* *}$ & $0 \cdot 48 \pm 0 \cdot 14^{* *}$ & $133 \cdot 5 \pm 8 \cdot 9 * *$ \\
\hline
\end{tabular}

Weights expressed as means \pm S.E.M. $-=$ Not measured.

** Significantly different from controls $(P<0 \cdot 01)$.

Microscopic examination of testes revealed extensive changes in the seminiferous tubules of busulphan-treated rats (Plate 1). The testes of 21-day-old control rats (Pl. 1, Fig. 1) exhibited several layers of dividing spermatogonia; by 40 days of age ( $\mathrm{Pl}$. 1, Fig. 3), spermiogenesis was apparent and elongated spermatids were frequently seen; testes from 60-day-old control rats (Pl. 1, Fig. 6) exhibited full spermatogenesis. Conversely, testes from rats previously exposed to busulphan (PI. 1, Figs 2, 4 and 6) were devoid of spermatogenic elements in all three age groups, containing only Sertoli cells in the seminiferous tubules. No changes in Sertoli cell or Leydig cell morphology were apparent.

The concentrations of testosterone in the sera of treated rats (Table 2) did not differ from those of controls at 21 days of age, tended to be lower (not significant) at 40 days, and were markedly lower $(P<0.01)$ in 60-day-old rats.

The levels of testosterone in the testes (ng/testis) also did not differ at 21 and 40 days, but control testes contained fourfold more testosterone $(P<0.01)$ at 60 days of age (Table 2). The concentrations of testosterone in the testes (ng/g wet weight) were higher in busulphan-treated rats at $21 \quad(P<0 \cdot 01)$ and $40(P<0.01)$ days, but did not differ from those of controls at 60 days of age (Table 2).

The histological appearance of testes in this study was similar to that found by other workers studying exposure of rats in utero to busulphan (Hemsworth \& Jackson, 1963; Gaulier \& Roux, 1970). All studies showed apparently selective destruction of all fetal spermatogenic tissues when female rats were treated at 
PI.ATE 1
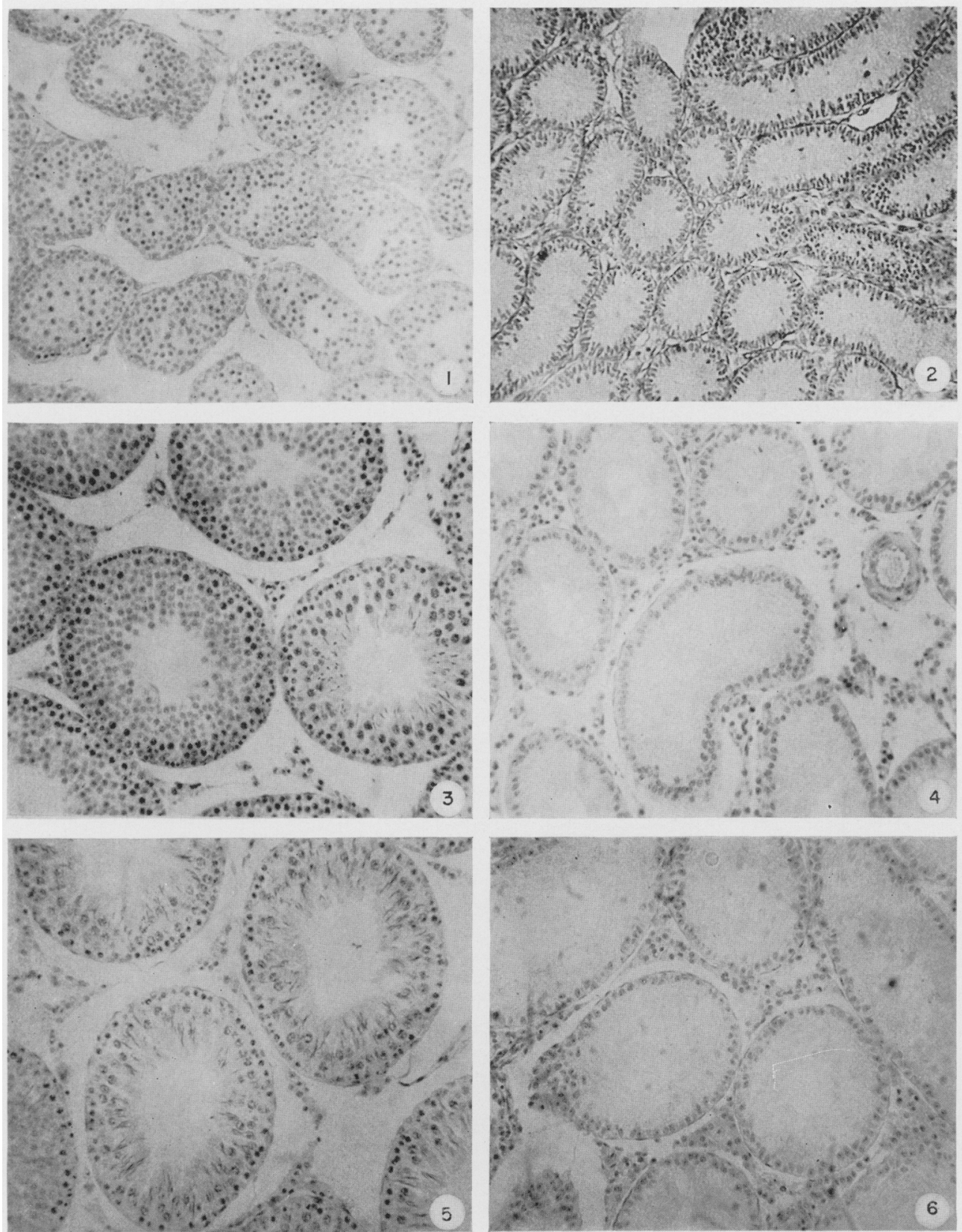

Photomicrographs representing cross-sections of testes from control rats and rats exposed to busulphan in utero. All $\times 123$.

Fig. 1. 21-day-old control rat.

FIG. 2. 21-day-old rat treated with busulphan.

FIG. 3. 40-day-old control rat.

Fic. 4. 40-day-old rat treated with busulphan.

FI'i. 5. 60-day-old control rat.

(Facing $f .132)$

Fic: 6. 60-day-old rat treated with busulphan. 
13 to 15 days of pregnancy; later treatment was less effective (Hemsworth \& Jackson, 1963), and earlier administration resulted in non-specific abnormalities (Gaulier \& Roux, 1970). Although no gross abnormalities were observed in this study, rats exposed to busulphan grew more slowly than controls; this may reflect differing androgen levels, but is more likely to reflect non-testicular effects of busulphan. If, for example, the normal development of the hypothalamus or the pituitary were also retarded by busulphan, deficiencies in growth hormone and gonadotrophins, which might be unrelated to spermatogenic function, could also explain the results found. Pinto-Machado (1970) reported a generalized deleterious effect on growth and vigour, and specific changes in the thymus, of mice exposed to busulphan during Days 13 to 18 of fetal life.

Table 2. Testosterone levels in serum and testes of rats treated prenatally with busulphan

\begin{tabular}{|c|c|c|c|c|c|}
\hline \multirow{2}{*}{$\begin{array}{c}\text { Age } \\
\text { (days) }\end{array}$} & \multirow[b]{2}{*}{ Group } & \multirow[b]{2}{*}{$\mathrm{n}$} & \multicolumn{3}{|c|}{ Testosterone levels } \\
\hline & & & $n g / m l$ serum & $n g /$ testis & ng/g testis wet wt \\
\hline 21 & $\begin{array}{l}\text { Control } \\
\text { Busulphan }\end{array}$ & $\begin{array}{r}14 \\
8\end{array}$ & $\begin{array}{l}0.9 \pm 0.2 \\
0.8 \pm 0.4\end{array}$ & $\begin{array}{l}11 \cdot 8 \pm 2 \cdot 6 \\
16 \cdot 9 \pm 3 \cdot 6\end{array}$ & $\begin{array}{l}103 \cdot 7 \pm 20 \cdot 9 \\
577 \cdot 5 \pm 118 \cdot 4^{* *}\end{array}$ \\
\hline 40 & $\begin{array}{l}\text { Control } \\
\text { Busulphan }\end{array}$ & $\begin{array}{r}10 \\
7\end{array}$ & $\begin{array}{l}7 \cdot 9 \pm 2 \cdot 3 \\
4 \cdot 1 \pm 3 \cdot 2\end{array}$ & $\begin{array}{l}4 \cdot 6 \pm 0.7 \\
7 \cdot 0 \pm 1 \cdot 8\end{array}$ & $\begin{array}{cl}3 \cdot 6 \pm & 0 \cdot 5 \\
34 \cdot 3 \pm & 9 \cdot 6^{* *}\end{array}$ \\
\hline 60 & $\begin{array}{l}\text { Control } \\
\text { Busulphan }\end{array}$ & $\begin{array}{r}10 \\
6\end{array}$ & $\begin{array}{l}3.4 \pm 0.7 \\
1.4 \pm 0.2^{* *}\end{array}$ & $\begin{array}{l}76 \cdot 0 \pm 6 \cdot 7 \\
17 \cdot 7 \pm 2 \cdot 6\end{array}$ & $\begin{array}{ll}27 \cdot 7 \pm & 2 \cdot 2 \\
34 \cdot 7 \pm & 7 \cdot 8\end{array}$ \\
\hline
\end{tabular}

Testosterone levels expressed as means \pm S.E.M.

** Significantly different from control $(P<0 \cdot 01)$.

If all of the changes recorded in this study are attributable, directly or indirectly, to effects of busulphan on the gonad, it appears that busulphan affects Leydig cells as well as seminiferous tubules, and testicular-hypophysial relationships at puberty are altered by these effects. If the Leydig cells were unaffected by embryonic exposure to busulphan, one would expect testosterone levels in the gonad (i.e. ng/testis) and the serum to be the same in treated and control rats, barring effects caused by differences in blood flow. Since the testes of treated rats are smaller due to loss of spermatogenic tissue, the concentration of testosterone in the testes (i.e. $\mathrm{ng} / \mathrm{g}$ tissue) might be expected to reflect the higher proportion of tissue comprised of Leydig cells; thus, concentrations in treated animals should be higher than in controls in proportion to loss in testis weight. Although these general patterns are seen in rats before and during puberty, adult rats show patterns that must be attributed to failure of the Leydig cells to produce normal amounts of testosterone. Whether this is due to decreased levels of gonadotrophin or to decreased ability of the testis to respond to circulating gonadotrophin remains to be studied.

In view of the apparent effects of busulphan treatment on Leydig cells in the developing testis, it appears likely that other tissues in the testis, especially the Sertoli cell, may also be abnormal in treated animals. Until this question is resolved, the use of busulphan induction of 'Sertoli cell only' preparations to study androgen metabolism in the testis would appear premature. 
This work was supported in part by USPHS Grant No. HD 03822. The authors are indebted to Dr S. A. Tillson, Alza Corporation, Palo Alto, California, for his generous gift of testosterone antiserum; to the Burroughs Wellcome Company, Raleigh, N.C., for supplying the busulphan, and to Mr T. G. Logan for technical assistance.

\section{REFERENCES}

Debeljuk, L., Armura, A. \& Schally, A. V. (1973) Pituitary and serum FSH and LH levels after massive and selective depletion of the germinal epithelium in the rat testis. Endocrinology, 92, 48.

Gaulier, M. \& Roux, G. (1970) Action du busulfan sur la lignée germinale de l'embryon de rat. C. r. Séanc. Soc. Biol. 164, 2165.

Gomes, W. R., Hall, R. W., Jain, S. K. \& Boots, L. R. (1973) Serum gonadotropin and testosterone levels during loss and recovery of spermatogenesis in rats. Endocrinology, 93, (in press).

HaRvey, W. R. (1960) Least-squares analysis of data with unequal subclass numbers. Dep. Bull. U.S. Dep. Agric. ARS 20-8.

Hemsworth, B. N. \& JACKson, H. (1963) Effect of busulphan on the developing gonad of the male rat. 7. Reprod. Fert. $5,187$.

Pinto-Machado, J. (1970) Influence of prenatal administration on the postnatal development of mice. Production of a syndrome including hypoplasia of the thymus. Teratology, 3, 363 . 